Tung N. s.,

Dap N. D.

\title{
ANALYSIS OF THE BIODIVERSITY AND SOCIO-ECONOMIC VALUES OF THE WETLANDS IN VIETNAM
}

Об’єктом дослідження є біорізноманіття та гуманістичні екологічні цінності водно-болотних угідь та негативний вплив соціально-економічного розвитку на екосистему водно-болотних угідъ. Запропоновано практичні рішення щодо збереження, управління та сталого використання водно-болотних ресурсів для сталого розвитку В'єтнаму. Площа водно-болотних угідь В'єтнаму становить близько 12 мільйонів гектарів, що становить одну третину всієї природної території. Водно-болотна екосистема В'єтнаму володіє високим рівнем біорізноманіття, містить різні важливі екологічні функиї та цінності, безпосередньо впливає на життєдіяльність людей та відіграє важливу роль в соціально-культурному житті країни. В'єтнам має 9 ділянок, позначених як водно-болотні угіддя міжнародного значення (Рамсарські ділянки - водно-болотні угіддя міжнародного значення). Однак деякі водно-болотні угіддя все більше деградують як за якістю, так i за кількістю видів через надмірну експлуатачію та надмірне використання. У чій роботі використовувалися різні методи дослідження, включаючи кабінетне дослідження, вторинний аналіз $і$ загальну швидку оцінку (PRA), яка проводиться для збору даних від осіб, які приймають рішення, $і$ спільноти в Національному парку Суантхуй (провіниія Намдінь) і в Національному парку Чамчім (провінція Донг Тхап). В результаті проведених досліджень було показано, що основними проблемами водно-болотних угідь у В'єтнамі є: нестійка експлуатація; незбалансоване використання та збереження водно-болотних угідь; відсутність всеосяжних даних про водно-болотні угіддя для задоволення вимог управління водно-болотними угіддями та сталого розвитку. Збереження та використання водно-болотних угідь у В'єтнамі має здійснюватися за принципом наближення до екосистеми, що забезпечує збереження всієї структури, функцій, екологічних характеристик та біорізноманіття водно-болотних угідъ. Для чого автори рекомендують підвищити роль та участь громад, що проживають у водно-болотних угіддях і навколо них, а також зацікавити сторони у збереженні та стійкому використанні водно-болотних угідь. Забезпечити справедливий та рівноправний механізм розподілу вигод, заснований на рівних правах $і$ обов'язках зацікавлених сторін у використанні екосистемних послуг водно-болотних угідъ.

Ключові слова: водно-болотні угіддя В'єтнаму, болотна екосистема, біорізноманіття, збереження екосистеми, управління водно-болотними угіддями.

\section{Introduction}

Wetlands provide important ecosystem services for the prosperous development in various countries, providing resources for several economic sector development such as fisheries, agriculture and tourism. Rice grown from the wetlands is the staple food for about 3 billion people, accounting for about $20 \%$ of the global nutritional consumption [1]. The wetland regions are also the place where cultural and belief activities take place; providing accommodation, entertainment, and significant contribution to the development of the tourism. Nowadays, the wetlands provide livelihoods for more than 1 billion people across the global [1-3].

Specially, wetland shows the immense ability of carbon capture and storage (e. g. peatlands containing $30 \%$ of the surface carbon), water purification and flow change, climate regulation, limiting floods, deposition of sediments for soil formation, and active participation in the nutritional circulation of the global ecosystem [1].
Wetland is also an important «cradle» of biodiversity, $40 \%$ of all species on Earth live and breed in the wetlands [2]. The biodiversity of the wetland contributes to cleaning up water sources and pollutants; prevent and minimize impacts of storms; especially, mangrove ecosystems and coral reefs are the biological shields to protect coastal areas.

However, wetlands are seriously degrading on a global scale. Scientific research show that $64 \%$ of the total wetland areas on earth have been disappeared since 1900. The number is approximately $87 \%$ if the lost since 1700 counted $[1,4]$. Along with the wetland decline, according to the World Wildlife Fund (WWF), aquatic population have also decreased by $76 \%$ during 1970 and 2010 [5]. This situation seems to be more significant in case there is a lack of strong action to conserve the wetlands taken places by nations. Excessive degradation of wetland will lead to ecological imbalance and threaten food security and human society development.

Vietnam's wetland ecosystem has a high level of biodiversity, providing important human and ecological values. 
However, many wetland areas of Vietnam are experiencing a decline in both quality and quantity of animal and plants due to over-exploitation and over-use. Therefore, it is necessary to conduct studies and assess the current situation and adverse impacts of the socio-economic activities, thereby proposing solutions to protect and sustainably use the wetland resources [5-7]. Thus, the object of research is biodiversity and humanistic ecology values of the wetlands and the negative impacts of the socioeconomic development on wetland ecosystem. And the aim of research is analysis of the biodiversity and humanistic ecology values of the wetlands and the negative impacts of the socio-economic development on wetland ecosystem and further offering practical solutions for the conservation, management and sustainable use of the wetland resources for the sustainable development of Vietnam.

\section{Methods of research}

The study utilized various research methods including desk research, secondary analysis, and Participatory Rapid Appraisal (PRA)

First, the research collects, summarizes and analyzes data in previous studies of biodiversity, values of Vietnam's wetlands, and the challenges of socio-economic development to environment and biodiversity of the wetlands.

Participatory Rapid Appraisal method is carried out to collect data from decision makers and community in Xuan Thuy National Park (Nam Dinh province) and in Tram Chim National Park (Dong Thap province).

\section{Research results and discussion}

3.1. The ecological values of Vietnam's wetlands. Vietnam currently has 9 sites designated as Wetlands of International Importance, with a surface area of 120,549 hectares [3], including Xuan Thuy National Park, Bau Sau wetland in Cat Tien National Park, Ba Be Lake, Tram Chim National Park, Mui Ca Mau National Park, Con Dao National Park, Ramsar Lang Sen, U Minh Thuong National Park, and Van Long Nature Reserve. Xuan Thuy Wetland which belongs to Xuan Thuy National Park, Nam Dinh province is the first Ramsar Site in Southeast Asia, and the $50^{\text {th }}$ in the world $[8,9]$. As scientific evaluation, Vietnam has more than 25 wetland areas meeting the criteria of the Wetlands of International Importance according to the Ramsar Convention [10].

According to the Ministry of Natural resources and Environment's classification, there are 26 different types of wetlands in Vietnam, including coastal and marine wetlands, and domestic and artificial wetlands [11]. Wetlands are comprised of two groups: inland wetlands and coastal wetlands. The Mekong Delta within Vietnam territory is the furthest downstream portion of the Mekong River Basin. The Mekong Delta has a total area of approximately 3.9 million hectares, occupying about $12 \%$ of the total natural area of the country, including thirteen provinces and cities [12-14].

With a total area of about 12 million hectares, accounting for $37 \%$ of the natural area, including more than 7.3 million hectares of agricultural cultivation, the wetland areas of Vietnam are subject to development of industries and other economic sectors [9]. Today, $20 \%$ of the Vietnamese population lives in the wetlands and directly depends on the exploitation and use the wetland resources and products. Some wetland areas are known as place of residence, creating civilization for Vietnamese people - the «wet rice» civilization [15, 16].

In addition, Vietnam is located in the tropical region, considered to be one of the centers of high biodiversity in the world. Biodiversity is the basis of survival for all creatures, providing people with food sources, crucial medicinal materials, raw materials for industry, construction, health protection, culture and aesthetics.

The diversity of Vietnam's wetland types supports a wealth of species of both global and national significance, notably numerous fish, bird and invertebrate species, including many endemic and globally threatened species. To date, 1,028 fish species and 800 invertebrate species have been recorded in freshwater ecosystems in Vietnam. Of the 79 species of carp fish (Cyprinidae) found in the country, there is one endemic sub-family comprising 40 species and sub-species (Table 1). The particular significance of wetlands for birds is well demonstrated by the Dong Thap Muoi area in the Mekong Delta (or «Plain of Reeds»), which harbors 138 bird species from 49 families, representing $25 \%$ of all bird species found in Vietnam, including 16 globally threatened species. Wetlands are also home to 39 endemic Crustacean species (particularly shrimps and crabs) and 4 endemic mollusk species [14, 17]

Wetland of the Mekong Delta are among the richest ecosystem of the basin (tidal floodplains, coastal marshes, peatland marsh, estuaries etc.) and are important breeding sites of many aquatic species migrating from upper reaches of the Mekong River. According to a Map of wetlands in the Mekong Delta at a scale of 1:250,000, the wetland area covers 4,939,684 ha, which includes inland wetlands and coastal wetlands with a depth of less than six meters at low tide (Fig. 1) [4, 18].

Coastal and marine systems exhibit even higher species diversity with over 11,000 species recorded to date, including 6,300 benthic species, 2,500 fish species, 653 seaweed species, over 300 coral species, 94 mangrove tree species, 15 marine snake species and 25 marine mammal species. Additionally, five globally endangered marine turtle species are found in Vietnam, namely: the green turtle (Chelonia mydas), loggerhead turtle (Caretta caretta), Olive Ridley turtle (Lepidochelys olivacea), the critically endangered leatherback turtle (Dermochelys coriacea) and the hawksbill turtle (Eretmochelys imbricate). Fifteen species of dolphin and porpoise and one species of baleen whale have also been recorded, while the endangered dugong (Dugong dugon) has already been mentioned [2].

Some bird sanctuaries have been formed in the wetland areas of the countries. In particularly, there are more than 30 bird sanctuaries in the Mekong River Delta (the South) and the Red River Delta (the North) such as Bac Lieu 40 hectares, Dam Doi 120 hectares, Cai Nuoc 13 hectares, and Tram Chim with over 5,000 hectares [12].

Wetland species in Vietnam [9]

Table 1

\begin{tabular}{|c|c|}
\hline Aquatic species in freshwater wetlands & Species in coastal wetlands \\
\hline 157 species of protozoa & 460 species of scleratinian corals \\
403 species of algae & 15 species of seagrass \\
190 species of crustaceans & 667 species of seaweeds \\
147 species of bivalves & 94 species of mangroves \\
546 species of fish & about 1300 other species of fish and migratory birds \\
\hline
\end{tabular}




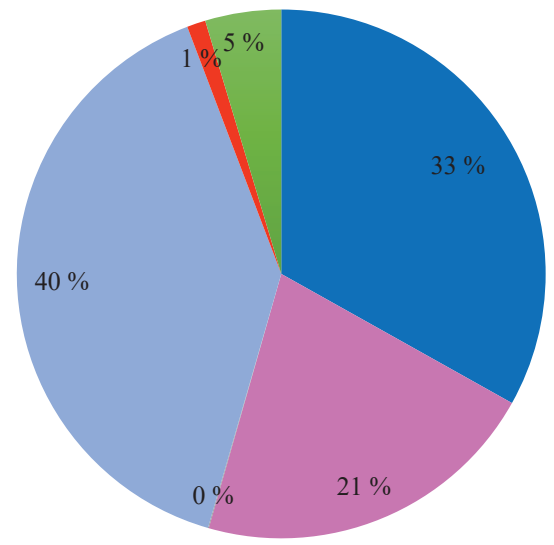

- Saline coastal wetlands, 1,636,069 ha

- Saline lagoons, 2,521 ha

n Freshwater lacustrine wetlands, 56,389 ha
- Saline estuarine wetlands, $1,052,102$ ha - Freshwater rivery wetlands, 1,963,240 ha

Marshes and swamps, 229,363 ha

Fig. 1. Areas of typical wetland types in the Mekong Delta

Vietnam's wetlands create livelihoods for millions of people, making an important contribution to the development of agriculture, fisheries, forestry, energy, water transport and tourism in the country. According to statistics [2, 3], the wetland areas have provided food and seafood for domestic demand and exports, which have reached over 10 billion USD in 2017. Over 20 million people have main income or partly income from aquatic resources [3].

Xuan Thuy is the $50^{\text {th }}$ Ramsar site worldwide (1989) and the first Ramsar site in the Southeast Asia. In 1995, Government decided to establish Xuan Thuy Wetland Natural Reserve in the area, which was upgraded to Xuan Thuy National Park (2003). Besides that, Xuan Thuy was acknowledged as the critical core zone of the Red River Delta Biosphere Reserve (2004). All of the national and international titles of Xuan Thuy Ramsar, Xuan Thuy National Park and Biosphere Reserve somehow reflect importance of this area in terms of biodiversity conservation, socio-economics, environmental and social education, and ecotourism [19-21].

Xuan Thuy National Park supports a total of 14 habitat types, including both natural and man-made ones [22]. The habitat types with the greatest biodiversity value are undisturbed mudflats and natural mangroves. The dominant mangrove species is Kandelia candel, although a few Sonneratia caseolaris have been planted, and Aegiceras corniculatum and Acanthus ilicifolius have spread naturally. Much of the mature mangrove at the site has been enclosed within aquacultural ponds, although large areas of mudflat in the south of the site have been planted with a monoculture of K. candel. In 1996, a 300 ha Phragmites sp. Reedbed occurred in aquacultural ponds on Ngan island. However, this reedbed had largely disappeared by 2000. Luu island supports extensive Casuarina equisetifolia plantations, which are an important habitat for migratory passerines [22].

As a result of its habitat diversity and relative intactness, Xuan Thuy National Park is an important staging and wintering area for migratory water birds. During surveys in 1988 and 1994 more than 20,000 water birds were observed. During the spring of 1996, it was estimated that more than 33,000 shorebirds passed through the national park [22].

Tram Chim National Park (Dong Thap province), located in the Mekong River Delta, has a natural area of 7,313 hectares. Tram Chim has become the 2,000 ${ }^{\text {th }}$ Ramsar
Site in the world and the $4^{\text {th }}$ of Vietnam in 2012. Tram Chim is an area of unique ecosystems, of crucial role for the surrounding areas and submerged ecosystems, which habitat diverse rare, endemic and migratory species. Oustandingly, Tram Chim is known to be home to the famous Easter Sarus Crane (Grus antigone sharpii), along with many rare and precious birds such as: spur-winged goose (Plectropterus gambensis), great cormorant (Phalacrocorax carbo), painted stork (Mycteria leucocephala), spot-billed pelican (Pelecanus philippensis), and lesser adjutant (Leptoptilos javanicus). The Tram Chim's typical wetland is also the habitat of many species of fish listed in the Vietnam Red List (2007) such as clown knifefish (Notopterus chitala), cottonmouth (Agkistrodon piscivorus), hampala barb (Hampala macrolepidota), Small scale mud carp (Cirrhinus microlepis), black sharkminnow (Labeo chrysophekadion), and Giant barb (Catlocarpio siamensis) [10, 18].

3.2. Adverse impacts threatening Vietnam's wetlands. There are a few countries have a rich and diversified wetland areas, which is as widely distributed as in Vietnam. However, Vietnam's wetlands are increasingly negative affected by human economic development activities and climate change. In particular, Vietnam's wetlands have been strongly exploited for tourism industry development in the last few decades. Many wetland areas are known as the attractions of many domestic and foreign tourists such as Cat Ba Island, Con Dao Island, Phong Nha - Ke Bang, Can Gio, Ba Be, and Tram Chim. For example, hazard characteristics of the coastal wetlands (Table 2).

Many wetland areas have been lost or degraded due to the pressure of exploitation and use of the natural resources for socio-economic development, which have reduced the quality of land and water, changed the structure and function of ecosystem services in many wetland areas across the country, seriously reduced biodiversity; and over-exploited the number of endangered and rare species. According to the International Union for Conservation of Nature (IUCN) Red List of Threatened Species (2012), there is at least 135 species of globally threatened residing in its continental freshwater habitats, tidal flats, and coastal areas [23].

The reduction in natural wetland areas is also down to rice production, aquaculture, reservoir construction and mineral exploitation. Along with shrinking areas, the wetlands face serious degradation caused by industrial waste, oil and chemical substances used in agriculture and aquaculture production.

Reports on the national environment status released by the Ministry of Natural Resources and Environment [5] showed that industrial and export processing zones in the southern region discharged to the Dong Nai and Saigon rivers over $111,600 \mathrm{~m}^{3}$ of wastewater. Solid waste accounted for 15 tonnes, with 1.6 tonnes of nitrogen and $500 \mathrm{~kg}$ of phosphate. Meanwhile, the rising use of plant protection substances in the River Delta region was alarming. The content of the chemical substances measured at the mouth of the Red River was 23 to 28 times higher than the norm. This was one of reasons for recent incidents of fish dying en masse in rivers and waterways. Along with human activities, climate change is putting pressure on wetland ecosystems. 
Hazard characteristics of the coastal wetlands

\begin{tabular}{|c|c|c|c|c|}
\hline Hazard & Distribution & Intensity & Frequency & Incidence \\
\hline Erosion & $\begin{array}{l}\text { Along the banks of Red } \\
\text { river, Mekong River etc. }\end{array}$ & $\begin{array}{l}\text { High rate, } \\
\text { 8-10 mm/year }\end{array}$ & Annual & Loss of lowland and wetland \\
\hline Channels siltation & Along the coastal zones & High deposition rate & Frequently & Inhibit waterway transport \\
\hline Typhoons and flood & $\begin{array}{l}\text { Coastal lowland area that } \\
\text { has weak drainage system } \\
\text { terгain }\end{array}$ & Duite hard & $\begin{array}{l}\text { 1-2 typhoons/year } \\
\text { Frequently }\end{array}$ & Inundation of coastal агеа \\
\hline $\begin{array}{l}\text { Climate change } \\
\text { and sea level rise }\end{array}$ & Coastal lowland, wetland & Duite hard & Frequently & $\begin{array}{l}\text { Loss coastal lowland, natural } \\
\text { resources and wetland ecology system }\end{array}$ \\
\hline $\begin{array}{c}\text { Enviranmental pollution } \\
\text { (industry, agriculture, plastics } \\
\text { waste and other activities) } \\
\end{array}$ & Along all of coastal areas & Average-high & Increase by years & $\begin{array}{l}\text { Water and sediments environment, ecol- } \\
\text { ogy and human }\end{array}$ \\
\hline $\begin{array}{l}\text { Deforestation, construction of } \\
\text { infrastructure } \\
\end{array}$ & Coastal areas & Quite hard & Increase by years & Loss wetland forest \\
\hline $\begin{array}{l}\text { Expanding agricultural activi- } \\
\text { ties, seafood aquaculture }\end{array}$ & $\begin{array}{l}\text { Wetland zones in Red river } \\
\text { delta, Mekong river delta }\end{array}$ & High & Increase by years & Loss of natural wetlands \\
\hline $\begin{array}{l}\text { Over-exploitation and over- } \\
\text { use of natural resources } \\
\text { (water, fish, coral etc.) }\end{array}$ & Coastal areas & Average-high & Increase by years & $\begin{array}{l}\text { Loss of biodiversity, water resource, local } \\
\text { reduction or loss of species in a certain } \\
\text { habitat }\end{array}$ \\
\hline
\end{tabular}

The major threats and challenges to Xuan Thuy National Park are a high growth rate of population $(1.7 \%$ per year) with high population density $\left(1,246\right.$ persons $\left./ \mathrm{km}^{2}\right)$, a lack of appropriate of human capacity, weak community awareness and impacts of global climate change [24, 25].

Biodiversity of Tram Chim is seriously threatened. According to IUCN, in 1980s the numbers of Eastern Sarus Crane were drastically fell from 1,000 to 11 individuals during the period of 1980-2018 [26]. Eastern Sarus Crane is no longer migrating to Tram Chim due to the habitat loss in the entire distribution area of the creature populations. Moreover, the inadequate habitat management has prevented the crane's food source from growing. This loss is unfortunately irreversible (Fig. 2) [27].

Despite the Decree No. 109/2003/ND-CP of September 23,2003 , issued to directly adjust to the management of wetlands, this is no longer relevant to the policy context and does not meet the requirements of current practice after more than 17 years of implementation with regards to [2]:

1. The management, restoration and sustainable use of the wetland areas with biodiversity values has not been fully regulated especially the conservation areas of the wetlands and Ramsar areas.

2. Lack of regulations on benefit sharing mechanisms among stakeholders in the wetland use.

3. Lack of supporting policies for biodiversity conservation in the wetland areas.

4. The legal guidance of the Decree has changed.

Improper awareness on the importance and values of wetlands, many wetland areas are even considered fallow lands. Policies for changing land use purposes such as changing from shallow land to wetland (by developing dam construction, reservoirs, aquaculture, and sea dykes) and the lack of legal provisions on protection, conservation and sustainable use of wetlands lead to pollution, degradation, narrowing of natural wetland area, as well as economic losses and negative affects on livelihoods of civilians [20, 28, 29].

There are many governmental management agencies and units, from the central to local levels, which have been given the functions and tasks to manage activities in the wetland areas.

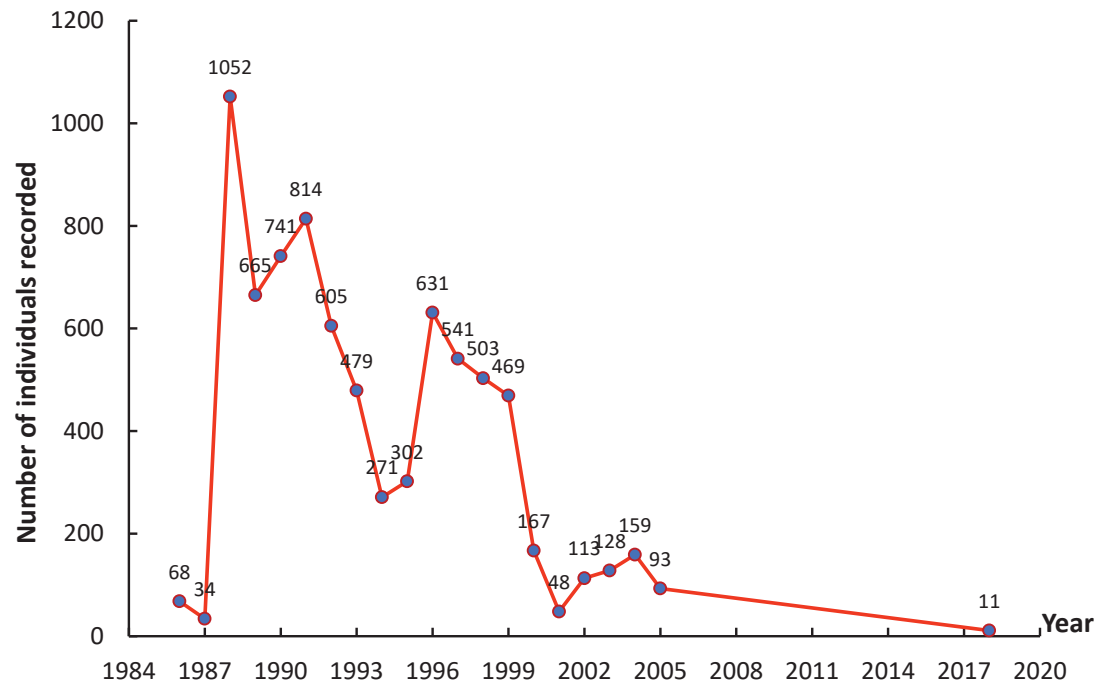

Fig. 2. Variation in individual numbers of Eastern Sarus Crane in Tram Chim National Park 
However, the assignments for those agencies and units are somewhat overlapped. The numbers and capacity of officials, especially specialized staffs in wetland management and governance, are insufficient and limited. There is no coordination mechanism in wetland management among relevant agencies and units. In addition, insufficient financial and investment resources in the wetland management have greatly affected the efficiency of the management of wetland ecosystems and protected areas.

3.3. The impacts of socio-economic development on Vietnam's Wetlands. The major direct drivers of wetlands degradation and loss in Vietnam to date are habitat loss and ecosystem degradation due to land use change, including outright conversion and fragmentation of wetlands, as well as ecological changes due to invasive alien species, pollution and overexploitation of certain species and of water resources. Climate change impacts are growing and are likely to have increasing impact on wetlands biodiversity in the medium to long-term.

The rapid socio-economic development of Vietnam has been associated with the expansion of agriculture, aquaculture and infrastructure, including roads, bridges, dams, harbors, rights-of-ways for electricity power-lines, sewage and water supply systems. This has resulted in the outright conversion of many natural habitats, including wetlands, into other forms of land use. Natural wetlands have been particularly vulnerable to conversion to agriculture, aquaculture and even forest plantations. For example, between 1943 and 2006, Vietnam lost at least 200,000 ha of mangrove forest, or about one third of its mangrove area, due to wars, deforestation and aquaculture development [14].

Deforestation and the construction of dams and other infrastructure in upper catchment areas are particularly detrimental to downstream wetlands. Wetlands are particularly vulnerable to changes in river flows due to the construction of dams, which can also reduce fish diversity and fishery yields as breeding migrations are obstructed and changes to patterns of flow, water temperatures and other, sometimes subtle, variations. Additionally, modifications in land use due to deforestation, agriculture and urbanization and infrastructure development will all affect surface water run-off patterns, reducing percolation and infiltration of water and increasing surface flow. Deforestation in the upper catchment also increases the sediment load of watercourses in the basin. In order to promote the rapid development of hydro-electric power in Vietnam, about 2,000 reservoirs have been constructed across the country to date, each with a volume of not less than 0.5 million cubic meters. In Thua Thien Hue province alone, a master plan to build 12 reservoirs by the year 2015 in the upper catchment of Huong and Bo rivers has been approved [14].

Agrochemicals, industrial and urban wastes are a major source of pollution to wetlands. A World Bank study on pollution in Vietnam's rivers found that industrial production, wastewater from mining and mineral sectors, even craft village, urban runoff and domestic wastewater contributed to pollution of rivers and coastal zones. Increased surface run off as a result of land use changes also increases the transportation of pollutants. The Red River Delta, in particular, has been subject to heavy agrochemical pollution. Some globally important species affected by wetland pollution in Vietnam include the critically endangered and endemic fish species Schistura spiloptera and the endemic globally endangered mollusk Cristaria truncate.

The main underlying causes of wetlands degradation and loss in Vietnam are the same as for biodiversity degradation and loss generally, namely the rapid pace of recent economic growth, much of which has been fuelled by the country's natural resource base. Population growth, agricultural expansion and intensification, industrialization and urbanization combined with changing patterns of consumption and waste production, have all increased pressure on Vietnam's biodiversity, including its wetlands biodiversity.

3.4. Proposed solutions for sustainable management and conservation of Vietnam's Wetlands. The $3^{\text {rd }}$ meeting of the Conference of the Parties defined the sustainable use of the wetlands as In order to continuously maximum benefit to the present generation while maintaining their potential to meet the needs and aspirations of future generations. Therefore, the conservation and sustainable development of the wetland areas must comply with the principle of strict protection of the wetland areas which has been zoned by the government for conservation purposes; combine the use and exploitation with conservation; prioritize conservation for wetland areas with specific ecosystems and high biodiversity and with the function of maintaining water sources and ecological balance at national and international levels; and enhance participation of communities living in the area and surrounding areas to the conservation of wetland areas [28].

The Ramsar Convention states: The wise use of wetlands as the maintenance of their ecological character, achieved through the implementation of ecosystem approaches, within the context of sustainable development [26]. Accordingly, the smart use of wetlands is the use of wetland areas for the benefit of humans, so as to be compatible with the maintenance of the natural attributes and functions of the wetland ecosystem, as well as the cooperate correlations among themselves and abide by the principles of the Ramsar Convention.

Vietnam has ratified the Ramsar Convention since 1989 and became the $50^{\text {th }}$ member of the Convention and the first country in the Southeast Asia to accede to the Convention. The Government of Vietnam has committed to establishing of system of typical wetland conservation areas. Based on the objectives of the Ramsar Convention, as a member state, Vietnam has implemented many activities to encourage and enhance the conservation of wetlands in terms of the establishment of nature reserves in the wetland areas and the development of strict protection measurements for the Ramsar sites and small and particularly sensitive reserves [30-32].

Applying an ecosystem approach to wetlands management in Vietnam. The ecosystem approach is a strategy for integrated management of land, water and living resources that promotes conservation and sustainable use in an equitable way. It's an innovative strategy that places human needs at the centre of biodiversity management. It aims to manage the ecosystem, based on the multiple functions that ecosystems perform and the multiple uses that are made of these functions. The ecosystem approach does not aim for short-term economic gains, but aims to optimize the use of an ecosystem without damaging it.

Accordingly, Vietnam has established numerous community-based models of wetland conservation and management. 
For example, mangrove management model in Dong Rui commune, Tien Yen district, Quang Ninh province; protecting nipa palm forest in Cam Thanh (Hoi An city, Quang Nam province); co-management and sharing of genetic resources in Xuan Thuy National Park and Ramsar (Xuan Thuy district, Nam Dinh province) and Tram Chim National Park (Thap Muoi district, Dong Thap province). Most outstandingly, the project of co-managing U Minh Ha National Park by allowing the community to grow fruit trees around the park, and at the same time being responsible for protecting ecosystems and contributing to preserving diverse biological value in the local.

Continue to promote communication, enhance public awareness about the importance of wetland areas to climate change adaptation; and at the same time, call for community commitment to conserve and sustainably use wetland areas and to stop activities that cause degradation of wetlands, and to promote the recovery of degraded wetlands. Relevant stakeholders should improve the implementation of the conservation and sustainable use of water resources and minimize the amount of drainage and water loss in the wetland areas to contribute to the fight against global climate change; integrate content of conservation and sustainable use of wetland areas in order to cope with climate change into programs, planning and development plans of industries and localities effectively and sustainably.

\section{Conclusions}

As a result of the research it is shown that Vietnam's wetlands play a key role in and contribute value to socio-economic development, cultural maintenance and development, disaster prevention, environmental protection, and preservation and development of biodiversity. With a total area of about 12 million hectares, accounting for $37 \%$ of the natural area, $20 \%$ of the Vietnamese population lives in the wetlands and directly depends on the exploitation and use the wetland resources and products. The wetland areas have provided food and seafood for domestic demand and exports, which have reached over 10 billion USD, over 20 million people have main income or partly income from aquatic resources.

However, wetland areas are strongly affected by human economic development activities, the major challenges to wetlands in Vietnam include: unsustainable exploitation, imbalanced utilization and conservation of wetlands, lack of comprehensive wetlands data to meet the requirements of wetland management and sustainable development.

For the sustainable use of wetlands in Vietnam must be carried out on the principle of approaching the ecosystem, ensuring the maintenance of the entire structure, functions, ecological characteristics and biodiversity of the wetland areas. For which the authors recommend increasing the role and participation of the communities living in and around the wetland areas and stakeholders in the conservation and sustainable use of the wetlands. A fair and equitable benefit sharing mechanism is ensured based on equal rights and obligations among stakeholders in the use of wetland ecosystem services.

\section{Acknowledgements}

This work was published under the grant «Environmental and industrial safety of technological processes as criteria for the potential effectiveness of complex systems» No. EE-002-2020.

\section{References}

1. Ramsar (2002). Review of internationally important wetland site Wetlands of International Important (Ramsar Sites).

2. Mai, L. (2020). Protection of wetland areas - Sustainable development of biodiversity resources. Journal Environment and Life, 2, 3-7.

3. Minh, T. (2020). Conservation and sustainable use of wetland areas. Nezespaper of Natural resources and Environment. Available at: https://baotainguyenmoitruong.vn/bao-ton-va-su-dungben-vung-cac-vung-dat-ngap-nuoc-298871.html

4. National Environment Agency (2001). Wetland in Vietnam: Biodiversity and Environmental values. MONRE Vietnam.

5. Vietnam Ministry of Natural resources and Environment (2017). Report of the Impact of government policies for conservation biodiversity of wetlands in Vietnam.

6. Nang, D. (2012). Wetlands protection and management in Vietnam. Proceding Wetland managementin Vietnam: Issues and Perspectives, $20-24$.

7. Magnus, T., Albert, M. S., Blake, D. R. (2003). Wetlands Management in Vietnam: Issues and Perspectives. Published by WorldFish Center. Available at: https://www.academia.edu/20866541/ Wetlands management in Vietnam issues and perspectives

8. Nhuan, M. T., Ninh, N. H., Huy, L. Q. et. al. (2003). Economic valuation of demonstration wetland sites in Vietnam. Vietnam wetland component report. Available at: https://www.iucn.org/ sites/dev/files/import/downloads/06_vietnam_economic_valuation_of_wetland_sites.pdf

9. Vietnam Environment Protection Agency (2005). Overview of wetland status in Vietnam after 15 years of Ramsar Convention. VEPA, IUCN, MWBP.

10. Hang, N. (2019). Wetlands of International Importance in Vietnam. Vietnam Environment Administration Magazine, 2, 6-8.

11. Thang, H. V., Duc, L. D. (2006). The Vietnamese wetlands classification system. Vietnam National Environment Agency.

12. Buckton, S. T., Cu, N., Tu, N. D., Quynh, H. Q. (1999). The conservation of key wetlands in the Mekong Delta. Birdlife International in Vietnam.

13. Thangm, D. N., Bennett, J. (2009). Estimating wetland biodiversity values: A choice modelling application in Vietnam's Mekong River Delta. Environment and Development Economics, 14 (2), 163-186. doi: http://doi.org/10.1017/s1355770x08004841

14. Institute of Strategy and Policy on Natural Resources and Environment (2014). Vietnam Conservation of Critical Wetland Protected Areas and Linked Landscape. ISPONRE.

15. Barbier, E. B. (1993). Sustainable Use of Wetlands Valuing Tropical Wetland Benefits: Economic Methodologies and Applications. The Geographical Journal, 159 (1), 22-32. doi: http:// doi.org/10.2307/3451486

16. Barbier, E. B. (1994). Valuing Environmental Functions: Tropical Wetlands. Land Economics, 70 (2), 155-163. doi: http:// doi.org/10.2307/3146319

17. IUCN (2008). Application of the ecosystem approach to wetlands in Vietnam. The International Union for Conservation of Nature. Available at: https://portals.iucn.org/library/sites/ library/files/documents/2009-060.pdf

18. Tran, T., Barzen, J. (2016). Tram Chim: Mekong River Ba$\sin$ (Vietnam). Springer Science. doi: http://doi.org/10.1007/ 978-94-007-6173-5_41-4

19. Tung, N. S., Nguyet, N. T. B., Nga, C. T. T. (2019). Impacts of socio-economic development on wetlands in Xuan Thuy Ramsar area, Nam Dinh province. Human Geography Reviez, 4 (27), 10-16.

20. Tinh, T. T. K., Hai, N. X., Quang, P. V., Yen, N. T. (2014). Variation of soil, water quality and impacts on biodiversity in Xuan Thuy Ramsar site. ARPN Journal of Agricultural and Biological Science, 9 (3), 84-88.

21. Tinh, T. T. K., Hoi, N. C., Hai, N. X. (2014). Wise use approach of wetlands - case study in Xuan Thuy Ramsar site. ARPN Journal of Agricultural and Biological Science, 9 (4), 122-126.

22. Nhan, H. T. T., Hai, H. T., Canh, L. X. (2012). Biological diversity in Xuan Thuy National Park, Nam Dinh Province. Proceedings of the 5th Scientific Natinal Meeting of Econsystem and Biological Resources. 
23. Pedersen, A., Thang, N. H., Dung, V. V., Tri, H. T., Eames, J. C. (1996). The conservation of key coastal sites in the Red River Delta. Birdlife International in Vietnam.

24. IUCN (2019). IUCN Red List of threatened species. The International Union for Conservation of Nature. Available at: http:// www.iucnredlist.org/

25. Nhuan, M. T., Ngoc, N. T. M., Huong, N. Q., Hue, N. T. H. Tue, N. T., Ngoc, P. B. (2009). Assessment of Vietnam Coastal Wetland Vulnerability for Sustainable Use (Case Study in Xuanthuy Ramsar Site, Vietnam). Journal of Wetlands Ecology, 2, 1-16. doi: http://doi.org/10.3126/jowe.v2i1.1850

26. Ramsar (1971). Ramsar Convention on Wetlands. Ramsar, Iran. Available at: https://www.ramsar.org/sites/default/files/documents/pdf/res/key_res_vi.01e.pdf

27. Long, T. T. (2019). Status of biodiversity in Tram Chim National Park. Proceedings of workshop Management and Conservation of Wetland in Vietnam. Can Tho city. Available at: https:// tuoitre.vn/chi-con-11-seu-dau-do-ve-tram-chim-it-hon-truoc100-lan-20191011144053524.htm

28. Ramsar (2016). Handbooks for the wise of wetland. Ramsar Convention Secretariat.

29. GEF-SGP (2015). Marine biodiversity and wetlands conservation in Vietnam: Experiences from GEF small project. Global Environment Facility-UNDP.
30. Tung, N. S., Nga, C. T. T. (2019). Challenges for coastal wetlands in Thai Thuy district, Thai Binh province. Proceeding of the 11th Vietnam National Conference on Geographical Science 2019. Hue ciy.

31. Ngoc, K. T. T. (2012). Mainstreaming of wetland ecosystem services in policy planning process - Case of Vietnam. International Conference on Greater Mekong Subregion (GMS): Balancing Economic Growth and Environmental Sustainability, Asian Development Bank (ADB), 312-320.

32. Ngoc, K. T. T. (2015). Theoretical and practical study on mainstreaming of ecosystem services into wetland management and conservation in Vietnam. Hanoi: Vietnam National University.

Nguyen Song Tung, PhD, Senior Researcher, Deputy Director, Institute of Human Geography, Vietnam Academy of Social Science (VASS), Hanoi, Vietnam, e-mail: songtung711@gmail.com, ORCID: http:// orcid.org/0000-0001-6298-2116

Nguyen Dinh Dap, PhD, Researcher, Institute of Human Geography, Vietnam Academy of Social Science (VASS), Hanoi, Vietnam, e-mail: nguyendinhdap@gmail.com, ORCID: http://orcid.org/00000002-7865-7171 